\title{
Cloning and biochemical characterization of a novel lipolytic gene from activated sludge metagenome, and its gene product
}

\author{
Li JunGang ${ }^{1 \dagger}$, Zhang KeGui ${ }^{2 \dagger}$, Han WenJun ${ }^{1 *}$
}

\begin{abstract}
In this study, a putative esterase, designated EstMY, was isolated from an activated sludge metagenomic library. The lipolytic gene was subcloned and expressed in Escherichia coli BL21 using the pET expression system. The gene estMY contained a 1,083 bp open reading frame (ORF) encoding a polypeptide of 360 amino acids with a molecular mass of $38 \mathrm{kDa}$. Sequence analysis indicated that it showed $71 \%$ and $52 \%$ amino acid identity to esterase/lipase from marine metagenome (ACL67845) and Burkholderia ubonensis Bu (ZP_02382719), respectively; and several conserved regions were identified, including the putative active site, GDSAG, a catalytic triad (Ser203, Asp301, and His327) and a HGGG conserved motif (starting from His133). The EstMY was determined to hydrolyse $p$-nitrophenyl (NP) esters of fatty acids with short chain lengths $(\leq \mathrm{C} 8)$. This EstMY exhibited the highest activity at $35^{\circ} \mathrm{C}$ and $\mathrm{pH} 8.5$ respectively, by hydrolysis of $p$-NP caprylate. It also exhibited the same level of activity over wide temperature and $\mathrm{pH}$ spectra and in the presence of metal ions or detergents. The high level of stability of esterase EstMY with unique substrate specificities makes it highly valuable for downstream biotechnological applications.
\end{abstract}

\section{Introduction}

Lipolytic enzymes are ubiquitous $\alpha / \beta$ hydrolyzing enzymes existing in animals, plants, and microbes. The enzymes contain esterases (EC3.1.1.1) and lipases (EC3.1.1.3) which catalyze the hydrolysis and synthesis of fatty acid esters including acylglycerides [1]. Due to some useful features such as broad substrate specificity, stability in organic solvents and regio-/enantioselectivity, lipolytic enzymes of microbial origin are widely used in industrial biotechnology, such as production of fine chemicals, pharmaceuticals, and fine chemicals synthesis [2-4].

Modern biotechnology has a steadily increasing demand for novel biocatalysts, thereby prompting the development of new experimental approaches to find and identify novel biocatalyst-encoding genes. Based on the direct cloning of the metagenome [5] for the construction of large clone libraries, metagenomics allows access to new sequences, genes, complete pathways and their products by multiple screening possibilities. With

\footnotetext{
* Correspondence: hanwenjun_79@hotmail.com

† Contributed equally

'School of Life Sciences and Biotechnology, Mianyang Normal University. Mianyang, 621000, PR China

Full list of author information is available at the end of the article
}

the advent of the metagenome approach, the so far uncultured microorganisms (estimated to more than 99\%) [6-10] are now more readily accessible, resulting in an exponential increase in the number of potential biocatalysts. Indeed, the metagenomic approach was useful in mining novel lipolytic enzymes from environmental samples, and also, several genes encoding esterases have been isolated in metagenomic libraries prepared from highly diverse bacterial communities, including marine sediment [11-13], soils $[8,10,14,15]$, drinking water biofilm [10], pond and lake water [16,17], and tidal flat sediment [18]. Some of these enzymes display enhanced characteristics, therefore, searching for novel lipolytic enzymes still attracts considerable attention.

Pre-studies based on 16S rDNA library have extensively expanded our knowledge of microbial diversity in activated sludge from sewage treat plant, including members of varied un-culturable groups (unpublished data). Here, we report the cloning, sequence analysis, and biochemical enzymatic characterization of a novel esterase, EstMY, from an activated sludge derived metagenomic library. Our report demonstrates that metagenomics is a powerful approach in mining new industrial 
enzymes. The esterase EstMY constituted a new member of family IV of bacterial lipolytic enzymes.

\section{Materials and methods Sampling}

Activated sludge was collected from a sewage treatment plant treating nitrogen-containing aromatic wastewater on September 2008 in Mianyang City, SiChuan Province.

\section{Bacterial strains, plasmids, and culture}

The starting strains and plasmids used in this study are listed in Table 1. E. coli was grown at $37^{\circ} \mathrm{C}$ in LuriaBertani (LB) medium supplemented with appropriate antibiotics [19]. When required, ampicillin was added at a final concentration of $100 \mu \mathrm{g} / \mathrm{ml}$, kanamycin at $25 \mu \mathrm{g} / \mathrm{ml}$, and chloramphenicol, at $12.5 \mu \mathrm{g} / \mathrm{ml}$.

\section{DNA preparation and manipulation}

E. coli cells were transformed by the calcium chloride procedure [19]. Recombinant plasmid DNA was isolated by the method of Birnboim and Doly [20]. For sequencing, this DNA was further purified by polyethylene glycol precipitation [19]. Restriction enzymes, T4 DNA ligase and calf intestinal alkaline phosphatases were purchased from New England Biolabs (Ipswich, USA) or Takara (Tokyo, Japan) and used according to the manufacturers' instructions. BugBuster Ni-NTA His. Bind Purification Kit was purchased from Novagen (Code No. NV70751-3, Novagen).

\section{Construction of metagenomic DNA library and related sublibrary}

Activated sludge DNA extraction was carried out as previously described using SDS and proteinase $\mathrm{K}$ treatment [21], and removing humic acids (HAs) prior to DNA extraction was conducted by removing $\mathrm{HAs}$ buffer, 100 $\mathrm{mmol} / \mathrm{L}$ Tris- $\mathrm{HCl} \mathrm{pH} \mathrm{10.0,} 100 \mathrm{mmol} / \mathrm{L} \mathrm{Na}_{4} \mathrm{P}_{2} \mathrm{O}_{7} 100$ $\mathrm{mM}, \mathrm{Na}_{2} \mathrm{EDTA}, 1.0 \%$ PVP, $100 \mathrm{mM} \mathrm{NaCl}, 0.05 \%$ Triton X-100 [22]. Approximately $150 \mu \mathrm{g}$ of metagenomic DNA was run on a preparative pulsed-field gel (Bio-Rad CHEF DR ${ }^{\circ} I I I ; 0.1-40 \mathrm{~s}$ switch time, $6 \mathrm{~V} / \mathrm{cm}, 0.5 \times \mathrm{TBE}$ buffer, $120^{\circ}$ included angle, $16 \mathrm{~h}$ ) and the appropriate size of DNA ranging from 30-45 kb was isolated, electroeluted and dialyzed against $0.5 \times \mathrm{TE}$ buffer for further Fosmid library construction. The purified DNA fragments were end-repaired by End-repaired enzyme mix. After drop dialysis and concentration, the blunt-ended, 5'-phosphorylated DNA was ligated into the cloningready Copycontrol pCC1FOS vector, and the recombinant molecules were packaged into $\otimes$ phage followed by phage transfection to E. coli EPI300 by using protocols described in MaxPlax ${ }^{\text {tw }}$ Lambda packaging kit (Epicentre Biotechnologies, Madison, Wisconsin, USA). A fosmid clone showing strong lipolytic enzyme activity on a tributyrin agar plate was selected for further characterization and designated FosD11L2. The DNA was purified from the selected clone, partially digested with Sau3AI in order to obtain 3-5 kb DNA fragments, ligated to the pUC18 vector and transformed into E. coli TOP10 cells (Transgen). Transformants were selected on LB

Table 1 Starting bacterial strains and plasmids used in this study

\begin{tabular}{|c|c|c|}
\hline Strain or plasmid & Description & $\begin{array}{l}\text { Source or } \\
\text { reference }\end{array}$ \\
\hline \multicolumn{3}{|l|}{ Strains } \\
\hline E. coli TOP10 & 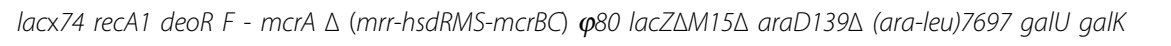 & Transgen \\
\hline E. coli EPI3007M-T1R & $\begin{array}{l}\text { [F- e14-(McrA-) D(mcrC-mrr) (TetR) hsdR514 supE44 supF58 lacY1 or D(laclZY)6 galK2 galT22 metB1 trpR55 } \\
\text { l-] }\end{array}$ & Epicentre \\
\hline E. coli BL21(DE3) & $F-$, ompt, hsdSB (rB-, mB-), dcm, gal, $\lambda(D E 3), p L y s S, C m r$ & Novogen \\
\hline $\begin{array}{l}\text { E. coli EPI300- } \\
\text { FosD11L2 }\end{array}$ & Positive clone from Fosmid genomic library, which carries the lipolytic gene & This study \\
\hline E. coli TOP10-EstMY & Positive clone from sublibrary, which carries the EstMY gene fragment & This study \\
\hline $\begin{array}{l}\text { E. coli BL21(DE3)- } \\
\text { EstMY }\end{array}$ & Positive clone, which carries the pEstMY-His expression vector & This study \\
\hline \multicolumn{3}{|l|}{ Plasmids } \\
\hline pCC1FOS & Cloning vector; $\mathrm{Ch}^{r}$ & Epicentre \\
\hline pUC18 & Cloning vector; $\mathrm{Ap}^{\mathrm{r}}$ & Takara \\
\hline pET28a & Expression vector; $\mathrm{Km}^{\mathrm{r}}$ & Novagen \\
\hline FosD11L2 & pCC1FOS, which carries the estMY gene cluster (31 kb) & This study \\
\hline pUC18-EstMY & pUC18, which carries the complete lipolytic gene (estMY) & This study \\
\hline pEstMY-His & pET28a carrying amplified HindIII -Ndel fragment containing lipolytic gene (estMY) & This study \\
\hline
\end{tabular}

$\mathrm{Ap}^{\mathrm{r}}$, ampicillin resistant; $\mathrm{Chl}^{\mathrm{r}}$, chloramphenicol resistant; $\mathrm{Km}^{\mathrm{r}}$, kanamycin resistant. 
(ampicillin, $100 \mu \mathrm{g} / \mathrm{ml}$ ) plates containing $1 \%(\mathrm{v} / \mathrm{v})$ tributyrin as the indicator substrate [23].

\section{Genetic characterization and sequence analysis}

The lipolytic DNA fragment obtained from positive clone E.coli TOP10-EstMY was sequenced with primer walking method by SinoGenoMax Co. Ltd (Chinese National Human Genome Center, Beijing). The ORFs were analyzed using DNASTAR (Lynnon Biosoft) software and ORF finder online analysis http://www.ncbi. nlm.nih.gov/projects/gorf/, Database searches for protein sequences was performed using BLAST and FASTA programs [24,25]. Peptide sequences of various enzymes or subunits were extracted from National Center for Biotechnology Information (Washington, D.C).

\section{Phylogenetic analysis}

Deduced amino acid sequences of 12 lipolytic enzymes were subjected to protein phylogenetic analysis. A phylogenetic tree was generated using the neighbor joining method of Saitou and Nei [26] with MEGA 4.0 software [27]. A total of 6 sequences were aligned with the CLUSTAL_W program [28] and visually examined with BoxShade Server program. The length of each branch pair represents the evolutionary distance between the sequences.

\section{Heterologous expression of gene estMY and purification of recombinant EstMY}

To express EstMY, the full length of the estMY gene was amplified by PCR with a pair of primers estMY-f and estMY-r (Table 2), in which the high fidelity PrimeSTAR ${ }^{\text {тм }}$ HS DNA Polymerase (code: DR010SA, Takara) was used. The integrity of the nucleotide sequence of all newly constructed plasmids was confirmed by DNA sequencing. The primer pairs with restriction enzyme sites (underlined) for HindIII and $\mathrm{NdeI}$ were designed to generate an $\mathrm{N}$-terminal His-tag of the recombinant esterase. The estMY gene was cloned into an expression vector, pET28a $(+)$ and the recombinant plasmid pestMY-His was transformed into $E$. coli BL21 (DE3) cells. When the cell density at $600 \mathrm{~nm}$ reached around 0.6, expression of recombinant EstMY protein was initiated by addition of $0.6 \mathrm{mM}$ isopropylthio- $\beta$-D-galactoside and continued cultivation for additional $4 \mathrm{~h}$. Cells were harvested by centrifugation at $5,000 \times \mathrm{g}$ for $5 \mathrm{~min}$, washed twice with ice-cold $50 \mathrm{mM}$ sodium phosphate buffer ( $\mathrm{pH} 8.0)$ and resuspended in the same buffer containing $10 \mathrm{mM}$ imidazole, disrupted by sonification in an ice-water bath (60 times, $5 \mathrm{~s}$ ). Recombinant EstMY esterase was applied to metalchelating chromatography using Ni-NTA affinity chromatography (Novagen) according to the manufacturer's instructions.

Polyacrylamide gel electrophoresis of enzyme in the presence of sodium dodecyl sulfate (SDS) was carried out by the method of Sambrook and Russell [19].

\section{Characterization of recombinant EstMY and biochemical properties}

The purified EstMY was subjected to a series of biochemical analysis, including determing the $\mathrm{pH}$ optimum, temperature optimum, substrate specificity, and effects of various detergents and metal ions. All measurements were carried out in triplicate. The values were the mean of the data. The substrate specificity of the purified EstMY protein was performed using the following substrates of $p$-NP-fatty acyl esters $[23,29]$ : acetate $(\mathrm{C} 2)$, butyrate $(\mathrm{C} 4)$, hexanoate (C6), caprylate (C8), decanonate $(\mathrm{C} 10)$, laurate $(\mathrm{C} 12)$, myristate $(\mathrm{C} 14)$ and palmitate (C16). The enzyme was incubated with the ester derivatives $(0.5 \mathrm{mM})$ in $5 \mathrm{ml}$ Tris- $\mathrm{HCl}$ buffer $(50 \mathrm{mM}, \mathrm{pH} 8.0)$ at $30^{\circ} \mathrm{C}$ for $10 \mathrm{~min}$. The reaction was quenched by adding $5 \mathrm{ml}$ trichloroacetic acid $(0.5 \mathrm{mM})$ and then recovered the original $\mathrm{pH}$ value with $5.15 \mathrm{ml} \mathrm{NaOH}$ $(0.5 \mathrm{mM})$. The enzymatic activity was measured by monitoring the $p$-nitrophenoxide production by absorbance at $405 \mathrm{~nm}$ against an enzyme-free blank, which

Table 2 Primers used in the study

\begin{tabular}{lll}
\hline Primer & Sequence 5'-3' $^{\prime}$ & Description \\
\hline HTFP061 & GTACAACGACACCTAGAC & Sequencing primer for pCC1FOS ${ }^{\text {TM }}$ \\
HTRP062 & CAGGAACAGCCTAGGAA & Sequencing primer for pCC1FOS ${ }^{\text {TM }}$ \\
M13 primer RV & CAGGAACAGCTATGAC & Sequencing primer for pUC18 \\
M13 primer M2 & AGCTGTTCACCGAAGGCTG & Sequencing primer for pUC18 \\
EstMY -W1F & CGCCCCTTCGACCAGCAACG & Genomic walking primer for estMY gene \\
EstMY -W2F & CTACGCCGACCTCACCGGCCT & Genomic walking primer for estMY gene \\
EstMY -W1R & GAGGGGTGGCGGGGATGCG & Genomic walking primer for estMY gene \\
EstMY -W2R & GACGTAGCCGCCGCCGTGAAG & Genomic walking primer for estMY gene \\
EstMY -R & GGCATATGGCCGCGCCCGTTCCGCCCATCAG Ndel & Forward primer for estMY gene \\
\hline
\end{tabular}

The Ndel and HindIII sites are underlined. The start codon is in bold. 
was measured using a Ultraspec $3000 \mathrm{UV} /$ vis spectrometer (Amersham Biosciences, Sweden) [30,31]. One unit of enzyme activity was defined as the amount of activity required to release $1 \mu \mathrm{mol} p$-NP per minute under the above condition. The highest activities of enzyme assay using the substrate (i. e. $p$-NP-caprylate) was defined as the $100 \%$. To determine the presence of esterase activity, the triglyceride derivative 1,2-di-Olauryl-rac-glycero-3-glutaric acid 6'-methylresorufin ester (DGGR) (Sigma Aldrich) was used as a chromogenic substrate, and the formation of methylresorufin was analyzed spectrophotometrically at $580 \mathrm{~nm}$ [32-34]. Candida rugosa lipase (Sigma Aldrich) was used as a positive control.

The optimum temperature of purified EstMY was determined by assaying lipolytic enzyme activities in a $50 \mathrm{mM}$ Tris- $\mathrm{HCl}$ buffer ( $\mathrm{pH} 8.0)$ for a temperature range of $20-65^{\circ} \mathrm{C}$, in which $p$-NP-caprylate $(0.5 \mathrm{mM})$ acted as substrate. Optimal $\mathrm{pH}$ was determined by examining the activity of the enzyme after incubation at $35^{\circ} \mathrm{C}$ for $10 \mathrm{~min}$ using $p$-NP-caprylate $(0.5 \mathrm{mM})$ as substrate. The buffers used were: $50 \mathrm{mM}$ phosphate buffer (pH 5.0-7.5), $50 \mathrm{mM}$ Tris- $\mathrm{HCl}$ (pH 8.0-10.5).

Various metal ions $\left(\mathrm{CoCl}_{2}, \mathrm{CaCl}_{2}, \mathrm{ZnCl}_{2}, \mathrm{MgCl}_{2}\right.$, $\mathrm{K}_{2} \mathrm{SO}_{4}, \mathrm{FeSO}_{4}, \mathrm{CuCl}_{2}, \mathrm{Ni}\left(\mathrm{NO}_{3}\right)_{2}$, and $\left.\mathrm{FeCl}_{3}\right)$, and chelating agent EDTA at final concentrations of $5 \mathrm{mM}$ were added to the enzyme in $50 \mathrm{mM}$ Tris- $\mathrm{HCl}(\mathrm{pH} 8.0)$, whereafter it was assayed for esterase activity following preincubation at $35^{\circ} \mathrm{C}$. Effect of detergents or reductors on esterase activity was determined by incubating the enzyme for $30 \mathrm{~min}$ at $35^{\circ} \mathrm{C}$ in $50 \mathrm{mM}$ Tris- $\mathrm{HCl}(\mathrm{pH}$ $8.0)$, containing Triton $\mathrm{X}-100$, Tween 20 , Tween 80 , $\beta$-mercaptoethanol, 1,4-dithiothreitol (DTT), sodium dodecyl sulfate (SDS), cetyltrimethyl ammonium bromide (CTAB), phenylmethanesulfonyl fluoride (PMSF), diethylpyrocarbonate (DEPC). The concentrations of metal ions, EDTA, detergents, and surfactants used were $5 \mathrm{mM}, 3 \mathrm{mM}$, and $0.5 \%(\mathrm{v} / \mathrm{v})$, respectively. The activity of the enzyme preparation in the absence of metal ions and detergents before incubation was defined as the $100 \%$ level.

\section{Nucleotide sequence accession number}

The DNA sequence of EstMY from activated sludge was deposited in GenBank under accession number of HM366454.

\section{Results and discussion}

\section{Construction and screening of a metagenomic library}

One hundred micrograms of prokaryotic DNA was extracted per gram of wet-weight activated sludge, and $1.5 \mu \mathrm{g}$ of size-selected, pulsed field gel-purified highmolecular-weight (HMW) DNA suitable for fosmid library construction was obtained. Three hundred nanograms of 30-45 $\mathrm{kb}$ purified metagenomic DNA was ligated into the copy control pCC1FOS vector and then tranfected into E. coli EPI300-T1 ${ }^{\mathrm{R}}$, producing a metagenome library of more than 7,0000 fosmids with insert size ranging from $27 \mathrm{~kb}$ to $38 \mathrm{~kb}$, with an average size of $32 \mathrm{~kb}$, covering approximately $2.1 \mathrm{Gbp}$ of the total metagenomic DNA. Given an average prokaryotic genome of approximately $5 \mathrm{Mbp}$, the metagenome library theoretically reached the size of over 400 prokaryotic genomes. The prokaryotic origin of the library was confirmed by end-sequencing of randomly selected fosmids and comparison with known ORFs in NCBI. Expression screening of the fosmid library for hydrolytic activity based on the hydrolysis of emulsified tributyrin (1\%) resulted in the finding of a recombinant clone, FosD11L2, forming a clear zone on the indicator plate. In order to identify the hydrolytic gene within a fragment of $31 \mathrm{~kb}$, the insert was subject to further subcloning.

\section{Subcloning and identification of the esterase gene}

The DNA insert $(31 \mathrm{~kb})$ of fosmid D11L2 was partial digested by Sau3AI and subcloned into prepared pUC18 vector, producing a subclone library of more than 3,000 clones with an average insert size of $3.5 \mathrm{~kb}$. One hundred and fifty subclones were screened for lipolytic activity. Among the 9 positive sub-clones forming a clear zone on the indicator plates, one sub-clone that expressed extracellular lipase/esterase activity was sequenced from both ends and the sequences were assembled into a contig of 2,680 bp. An ORF of 1,083 bp encoding a putative lipase/esterase (named EstMY) of 360 amino acids was identified. A second ORF encoding a putative lipolytic enzyme, designated EstMY-092, was identified as well as an additional putative ORF encoding a conserved hypothetical protein (Figure 1).

Amino acid sequence alignment indicated that this EstMY exhibited low identity with other esterase/lipases. EstMY shared the highest (71\%) sequence identity with the ACL67845 esterase/lipase isolated from a marine metagenome library, $65 \%$ sequence identity to Est25 screened from a soil metagenomic library [35], followed by the putative lipase/esterase from other environmental samples (50-65\% identity), the putative alpha/beta hydrolase from Burkholderia ubonensis $\mathrm{Bu}$ and Parvibaculum lavamentivorans DS-1 (ZP_02382719, 52\% identity; and YP_001412150, 49\% identity, respectively), members of the family IV hydrolases.

Various lipases and esterases contain the conserved active site motif of the pentapeptide GXSXG with a serine acting as the catalytic nucleophile, a conserved aspartate or glutamate and a histidine, together constituting a catalytic triad [2], organized in the $\alpha / \beta$ hydrolase fold [36]. The amino acid sequence alignment to 


\section{Conserved hypothetical}

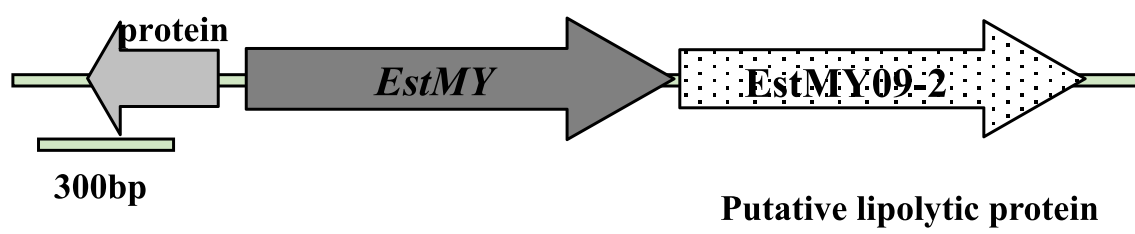

Figure 1 Sequencing of subclones (FosD11L2) expressing lipolytic activity resulted in the assembly of a 2,609 bp contig. Three major ORFs with conserved domains were identified: estMY, encoding a novel esterase EstMY; a putative conserved hypothetical protein, with homology to a cytidylate kinase; and an ORF (EstMY09-2) encoding a putative lipolytic protein.

bacterial lipolytic enzymes retrieved from GenBank http://www.ncbi.nlm.nih.gov, identified the conserved motifs, including the putative active site GDSAG (Figure 2). Thus, EstMY probably uses a catalytic triad consisting of the serine (Ser203) in the GDSAG active site, the aspartate (Asp301) and the highly conserved histidine (His327) for catalysis. Moreover, EstMY contains a HGGG conserved blocks (starting from His133), which corresponds to a family IV characteristic motif (HGG), which is in close proximity to the active site contributing to the formation of the oxyanion hole that is likely to participate directly in the catalytic process $[2,11,37]$. Furthermore, to clarify the phylogenetic relationship of the EstMY with other esterases or lipases, a neighbour joining phylogenetic tree was constructed using the amino acid sequence of the lipolytic enzymes. As shown in Figure 3. In this tree, EstMY formed a distinct group with the uncultured bacterium protein (AAX37295),

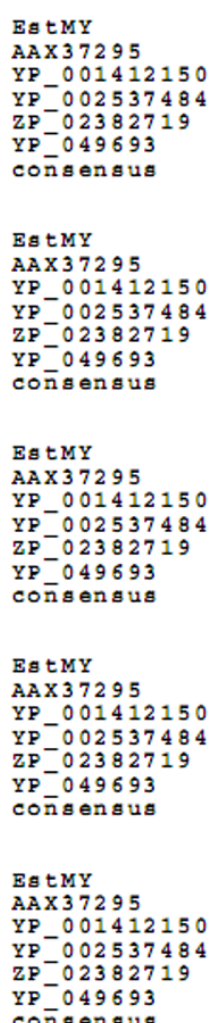

Figure 2 Conserved sequence blocks from multiple sequence alignment of EstMY from activated sludge metagenomic library and other related proteins. Sequences alignment was carried out with CLUSTALW [28] and BoxShade Server http://www.ch.embnet.org/software/ BOX_form.html. AAX37295, lipase/esterase from marine metagenome; YP_001412150, alpha/beta hydrolase domain-containing protein from Parvibaculum lavamentivorans DS-1; YP_002537484, alpha/beta hydrolase domain-containing protein from Methylobacterium populi BJ001; ZP_02382719, putative acetyl-hydrolase from Burkholderia ubonensis Bu; YP_049693, putative acetyl-hydrolase from Pectobacterium atrosepticum SCRI1043. 


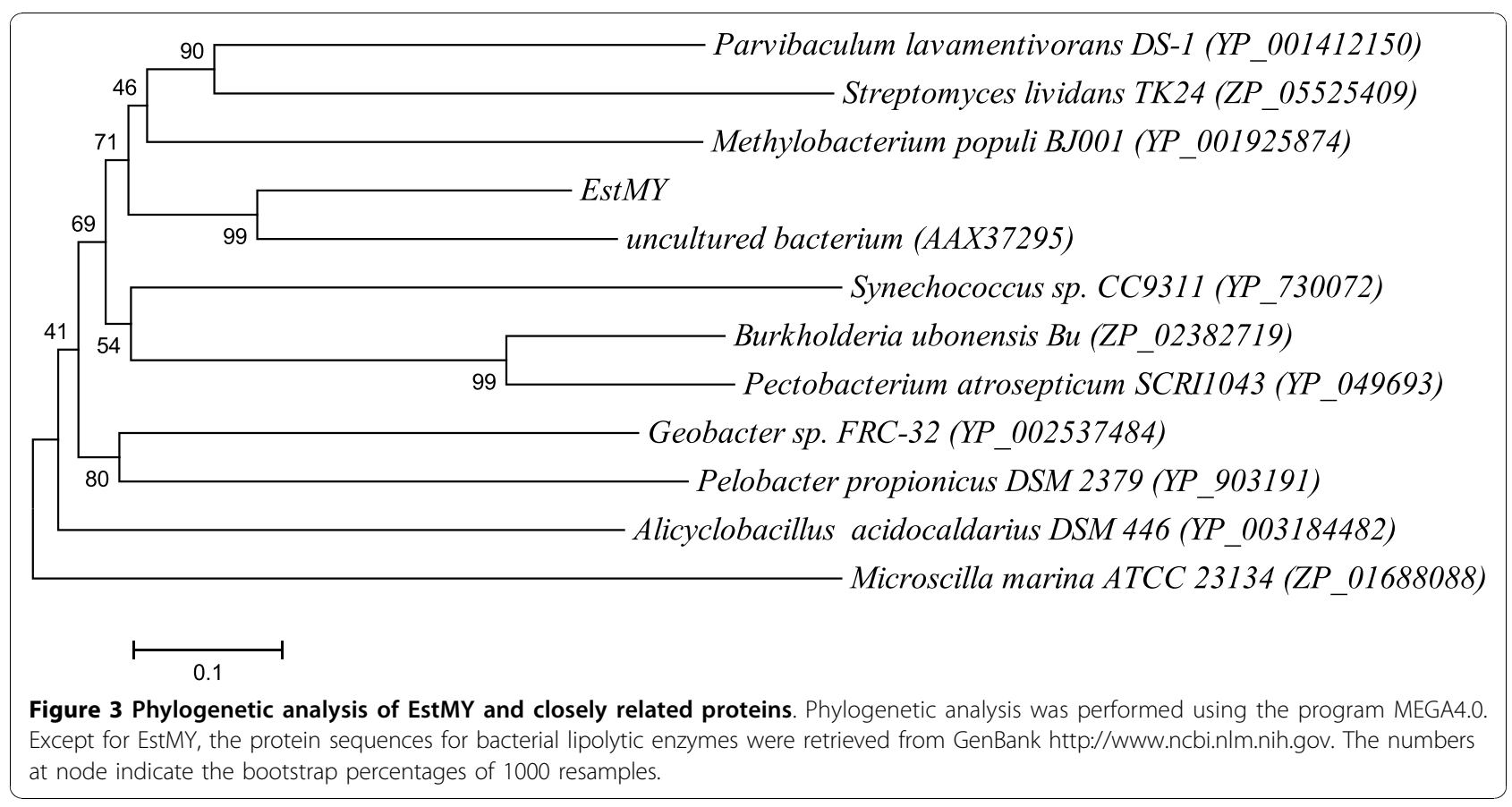

which is located closest to the branch of putative acetylhydrolase (accession number ZP_02382719) of strain Burkholderia ubonensis $\mathrm{Bu}$, esterase (accession number ZP_05525409) from Streptomyces lividans TK24, and also, alpha/beta hydrolase domain-containing protein (accession number YP_001412150 and YP_001925874 respectively) from Parvibaculum lavamentivorans DS-1 and Methylobacterium populi BJ001 respectively, which constitute family IV lipases. These results suggest that the EstMY is a new member of family IV lipases.

\section{Expression and purification of recombinant EstMY}

To investigate the property of this EstMY, estMY gene was expressed as an $\mathrm{N}$-terminal His-tag fusion protein using pET-28a(+) expression system in E. coli BL21 (DE3). The recombinant protein was analyzed by SDSPAGE and Coomassie brilliant blue staining (Figure 4). These results indicate that recombinant EstMY protein is expressed $(\mathrm{Mw}$, about $38 \mathrm{kDa})$, as which correlated well to the predicted full length of EstMY. The purity of the purified protein was more than $98 \%$ according to SDS-PAGE analysis.

\section{Substrate specificity of EstMY}

We expressed EstMY as a hexahistidine-tagged (Histagged) protein and investigated its chain length substrate specificity using $p$-nitrophenyl esters (Sigma). Results showed EstMY was able to hydrolyse $p$-nitrophenyl esters with acyl chains up to 14 carbons ( $p$-nitrophenyl myristate), with the highest activity towards short-chain fatty acids (C2, C4, C6 and C8), while much lower towards long-chain fatty acids ( $>$ C8) (Figure 5). Moreover, the EstMY was not able to hydrolyse the triglyceride derivative 1, 2-di-O-lauryl-rac-glycero-3-glutaric acid 6'-methylresorufin ester (DGGR) (data not shown), while DGGR was able to form chromogenic product methylresorufin by the true lipase from

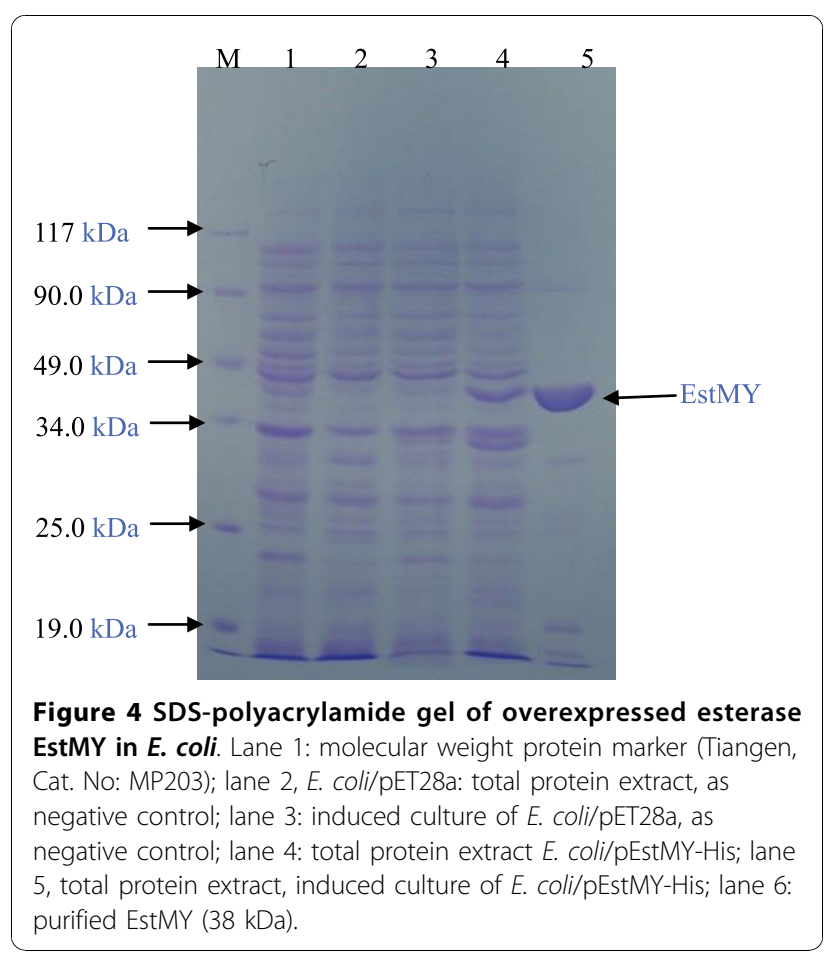




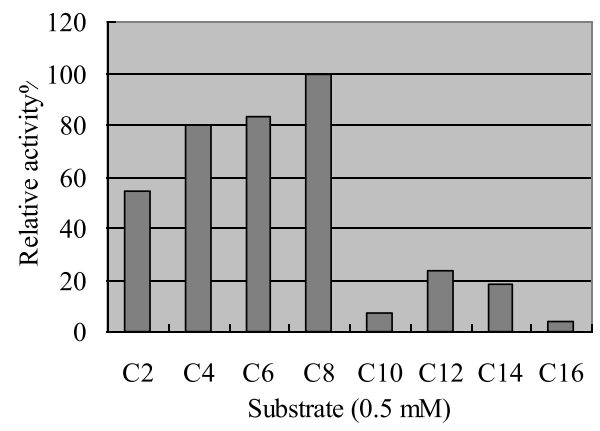

Figure 5 Substrate specificity of overexpressed and purified esterase EstMY. Specific activity of hydrolysis of different $p$ nitrophenyl esters. $p$-NP acetate (C2), $p$-NP butyrate (C4), $p$-NP hexanoate (C6), $p$-NP caprylate (C8), $p$-NP decanoate (C10), $p$-NP laurate (C12), $p$-NP myristate (C14), and $p$-NP palmitate (C16). Relative activity was shown as the percentage of the activity of the activity towards 4-nitrophenyl caprylate. All measurements were performed in triplicate.

Candida rugosa (positive control). Furthermore, EstMY showed no fluorescence on olive oil plates with rhodamine $\mathrm{B}$, which indicated that EstMY is a true esterase $[29,32,38,39]$.

\section{Effect of temperature and $\mathrm{pH}$ on EstMY}

Esterase activity of EstMY was determined from $20^{\circ} \mathrm{C}$ to $65^{\circ} \mathrm{C}$. The purified EstMY showed highest activity at $35^{\circ} \mathrm{C}$. It showed a broader temperature spectrum and retained over $37 \%$ activity at $65^{\circ} \mathrm{C}$ (Figure 6). However, h1Lip1 from marine sediment metagenome showed a bad thermostability because there was no activity left after incubation at $40^{\circ} \mathrm{C}$ for 30 minutes [29]. And also,

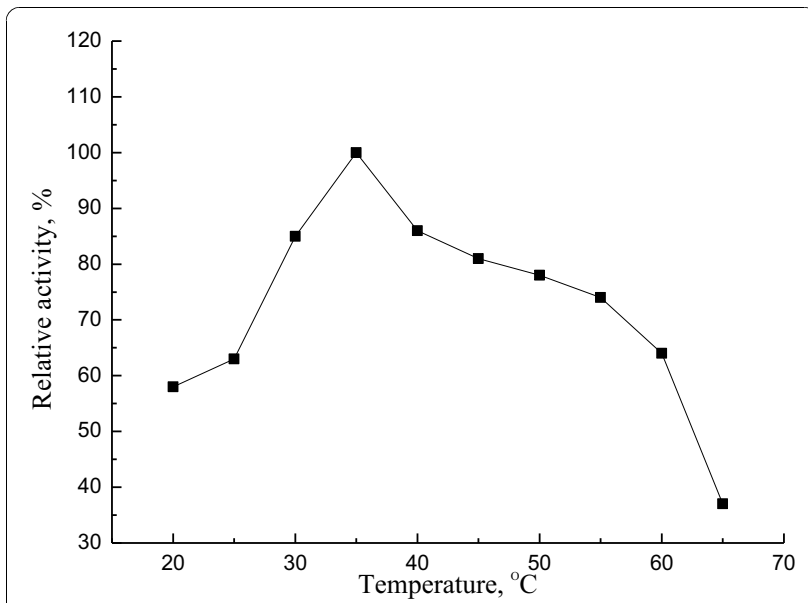

Figure 6 Apparent temperature optimum of esterase EstMY. Relative activity of $p$-NP-caprylate hydrolysis at different temperatures by purified EstMY. The activity was determined at different temperatures at $\mathrm{pH} 8.0$ in $50 \mathrm{mM}$ Tris- $\mathrm{HCl}$ buffer. The activity at $35^{\circ} \mathrm{C}$ was set as $100 \%(3,936 \mathrm{U} / \mathrm{ml})$. All measurements were performed in triplicate.

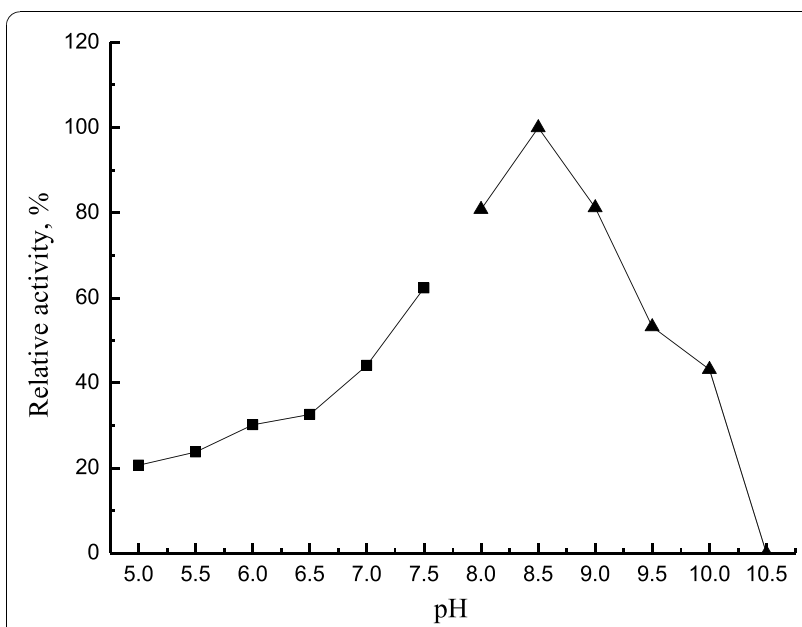

Figure $7 \mathrm{Effect}$ of $\mathrm{pH}$ on the purified esterae EstMY. Relative activity of $p$-NP-caprylate hydrolysis was performed in various $\mathrm{pH}$ buffers at $35^{\circ} \mathrm{C}$ (pH 5.0-7.5, $50 \mathrm{mM}$ phosphate buffer; $\mathrm{pH}$ 8.0-10.5, 50 $\mathrm{mM}$ Tris- $\mathrm{HCl}$ buffer). The activity at $\mathrm{pH} 8.5$ was set as $100 \%(4,615$ $\mathrm{U} / \mathrm{ml})$. All measurements were performed in triplicate.

the esterase showed activity in a rather broader $\mathrm{pH}$ range of 7.0-10.0. Maximal activity was observed at $\mathrm{pH}$ 8.5 and lost activity at $\mathrm{pH} 10.5$ (Figure 7).

\section{Effect of metal ions on esterase}

The effects of metal ions and ethylenediamine tetraacetic acid (EDTA) on the EstMY esterase activity were investigated by measuring the residual enzyme activity in their presence and depicted in Table 3. Among metal ions tested, the esterase activity was slightly increased by $\mathrm{Co}^{2+}(126 \%), \mathrm{Ca}^{2+}(104 \%)$ and $\mathrm{K}^{+}(103 \%)$. Furthermore, the esterase activity was inhibited by $\mathrm{Ni}^{2+}, \mathrm{Zn}^{2+}$, and $\mathrm{Mg}^{2+}$, moreover, almost totally inhibited by $\mathrm{Cu}^{2+}$, and $\mathrm{Fe}^{3+}$ ( $7 \%$ and $10 \%$ residual acitivity respectively), while the chelating agent EDTA had no effect, suggesting this esterase is not a metalloenzyme.

Table 3 Effect of metal ions on esterase activity

\begin{tabular}{llc}
\hline Compounds & Concentration (mM) & Relative activity (\%) \\
\hline Control & 0 & $100.0 \pm 2.9$ \\
$\mathrm{CoCl}_{2}$ & 5 & $126.4 \pm 2.1$ \\
$\mathrm{~K}_{2} \mathrm{SO}_{4}$ & 5 & $103.2 \pm 3.6$ \\
$\mathrm{FeSO}_{4}$ & 5 & $100.9 \pm 2.6$ \\
$\mathrm{CuCl}_{2}$ & 5 & $7.8 \pm 2.7$ \\
$\mathrm{Ni}\left(\mathrm{NO}_{3}\right)_{2}$ & 5 & $36.2 \pm 4.3$ \\
$\mathrm{EDTA}$ & 5 & $102.7 \pm 3.2$ \\
$\mathrm{FeCl}_{3}$ & 5 & $10.9 \pm 3.4$ \\
$\mathrm{CaCl}_{2}$ & 5 & $104.1 \pm 3.7$ \\
$\mathrm{ZnCl}$ & 5 & $23.7 \pm 1.8$ \\
$\mathrm{MgCl}_{2}$ & 5 & $79.7 \pm 2.6$
\end{tabular}

Activity without metal ions was set as $100 \%(4,897 \mathrm{U} / \mathrm{ml})$. All measurements were repeated three times. 
Table 4 Effect of detergents and enzyme inhibitors on esterase activity

\begin{tabular}{lll}
\hline Compounds & Concentration & Relative activity (\%) \\
\hline Control & 0 & $100.0 \pm 2.1$ \\
$\beta$-mercaptoethanol & $3 \mathrm{mM}$ & $101.7 \pm 2.6$ \\
DTT & $3 \mathrm{mM}$ & $106.9 \pm 4.9$ \\
CTAB & $3 \mathrm{mM}$ & $129.7 \pm 2.2$ \\
DEPC & $3 \mathrm{mM}$ & $38.6 \pm 2.7$ \\
PMSF & $3 \mathrm{mM}$ & $101.3 \pm 4.1$ \\
SDS & $3 \mathrm{mM}$ & $12.3 \pm 2.9$ \\
Triton X-100 & $0.5 \%$ & $129.6 \pm 4.6$ \\
Tween 80 & $0.5 \%$ & $138.4 \pm 2.1$ \\
Tween 20 & $0.5 \%$ & $156.7 \pm 3.3$ \\
\hline
\end{tabular}

Activity without detergents and enzyme inhibitors was set as $100 \%(4,970 \mathrm{U} /$ $\mathrm{ml}$ ). All measurements were repeated three times.

\section{Effect of detergents and reductors on esterase}

The effects of detergents and reductors on esterase activity are shown in Table 4. A significant increase in lipolytic activity was observed with addition of $3 \mathrm{mM}$ CTAB (130\%), 0.5\% Triton X-100 (129\%), Tween 80 (138\%), and Tween 20 (156\%), after $0.5 \mathrm{~h}$ preincubation with detergents at $35^{\circ} \mathrm{C}$. Moreover, $3 \mathrm{mM} \beta$-mercaptoethanol and DTT did not affect the lipolytic activity (101\% and 106\%, respectively), whereas DEPC and SDS had a strong inhibitory effect on esterase activity. In accordance to our results, Nawani et al. [40] also found a total inactivation of activity in the presence of SDS but an enhanced activity in the presence of Triton $\mathrm{X}-100$, Tween 80 , and Tween 20. Interestingly, the esterase EstMY activity was not impacted by $3 \mathrm{mM}$ PMSF, suggesting EstMY may possess a lid structure, which could eliminate the inhibition effect of PMSF. This is a special characteristic of carboxylesterases $[11,41,42]$ and site-directed mutagenesis of amino acid Ser203 will be carried out to confirm the function of Ser203.

In conclusion, we identified a new esterase EstMY belonging to family IV lipases, whose encoding gene was isolated from activated sludge of a sewage treatment plant treating nitrogen-containing aromatic wastewater. EstMY is expected to show high potential for downstream biotechnological applications including synthetic organic chemistry. This was confirmed by its extensive biochemical characterization, which revealed the enzymes substrate specificity, wide $\mathrm{pH}$ and temperature spectra, and also, stability towards addictives including metal ions and detergents. Future work will establish the structure of this enzyme to gain more information about its catalytic mechanism. Our research also demonstrated the potential of metagenome strategy in bioprospecting novel genes and biocatalysts and expanded our knowledge of biocatalyst diversity, especially for bacterial esterases. Enlargement of the lipases/ esterases pool can be an immediate source of genetic modification, or yield enzymes that can be further specialized by directed evolution, and also, this would optimize their industrial applications.

\section{Acknowledgements \\ This work was supported by the grant No. 2005B049 from the Scientific Reserch Fund of Sichuan Provincial Education Department.}

\section{Author details \\ ${ }^{1}$ School of Life Sciences and Biotechnology, Mianyang Normal University. Mianyang, 621000, PR China. ${ }^{2}$ Department of life science, Huainan Normal} University. Huainan, Anhui 232001, PR China.

\section{Authors' contributions}

$J G L$ participated in the design of experiments, and carried out the study and drafted the manuscript. KGZ carried out the SDS-PAGE experiment,

sequence alignment and enzyme characteristics analysis. WJH conceived the study, and participated in its design and coordination and helped to draft the manuscript. All authors read and approved the final manuscript.

\section{Competing interests}

The authors declare that they have no competing interests.

Received: 4 September 2010 Accepted: 7 November 2010

Published: 7 November 2010

\section{References}

1. Arpigny $\lrcorner$, Jaeger KE: Bacterial lipolytic enzymes: classification and properties. Biochem J 1999, 343:177-183.

2. Jaeger KE, Ransac S, Dijkstra BW, Colson C, van Heuvel M, Misset O: Bacterial lipases. FEMS Microbiol Rev 1994, 15(1):29-63.

3. Schmid A, Dordick JS, Hauer B, Kiener A, Wubbolts M, Witholt B: Industrial biocatalysis today and tomorrow. Nature 2001, 409(6817):258-268.

4. Straathof AJ, Panke S, Schmid A: The production of fine chemicals by biotransformations. Curr Opin Biotechnol 2002, 13(6):548-556.

5. Handelsman J: Metagenomics: application of genomics to uncultured microorganisms. Microbiol Mol Biol Rev 2004, 68(4):669-685.

6. Amann Rl, Ludwig W, Schleifer KH: Phylogenetic identification and in-situ detection of individual microbial cells without cultivation. Microbiol Rev 1995, 59(1):143-169.

7. Rappe MS, Giovannoni SJ: The uncultured microbial majority. Annu Rev Microbiol 2003, 57:369-394.

8. Lee SW, Won K, Lim HK, Kim JC, Choi GJ, Cho KY: Screening for novel lipolytic enzymes from uncultured soil microorganisms. App/ Microbiol Biotechnol 2004, 65(6):720-726.

9. Elend C, Schmeisser C, Hoebenreich $H$, Steele HL, Streit WR: Isolation and characterization of a metagenome-derived and cold-active lipase with high stereospecificity for (R)-ibuprofen esters. J Biotechnol 2007, 130(4):370-377.

10. Elend C, Schmeisser C, Leggewie C, Babiak P, Carballeira JD, Steele HL, Reymond $J$, Jaeger KE, Streit WR: Isolation and biochemical characterization of two novel metagenome-derived esterases. Appl Environ Microbiol 2006, 72(5):3637-3645.

11. Chu X, He H, Guo C, Sun B: Identification of two novel esterases from a marine metagenomic library derived from South China Sea. Appl Microbiol Biotechnol 2008, 80(4):615-625.

12. Park HJ, Jeon JH, Kang SG, Lee $J$ H, Lee SA, Kim HK: Functional expression and refolding of new alkaline esterase, EM2L8 from deep-sea sediment metagenome. Prot Expr Purif 2007, 52(2):340-347.

13. Jeon JH, Kim JT, Kim YJ, Kim HK, Lee HS, Kang SG, Kim SJ, Lee JH: Cloning and characterization of a new cold-active lipase from a deep-sea sediment metagenome. Appl Microbiol Biotechnol 2009, 81(5):865-874.

14. Henne A, Schmitz RA, Bomeke M, Gottschalk G, Daniel R: Screening of environmental DNA libraries for the presence of genes conferring lipolytic activity on Escherichia coli. Appl Environ Microbiol 2000, 66(7):3113-3116 
15. Li G, Wang K, Liu YH: Molecular cloning and characterization of a novel pyrethroid-hydrolyzing esterase originating from the Metagenome. Microb Cell Fact 2008, 7:38.

16. Rees HC, Grant S, Jones B, Grant WD, Heaphy S: Detecting cellulase and esterase enzyme activities encoded by novel genes present in environmental DNA libraries. Extremophiles 2003, 7(5):415-421.

17. Ranjan R, Grover A, Kapardar RK, Sharma R: Isolation of novel lipolytic genes from uncultured bacteria of pond water. Biochem Biophys Res Commun 2005, 335(1):57-65.

18. Wu C, Sun BL: Identification of novel esterase from metagenomic library of Yangtze river. J Microbiol Biotechnol 2009, 19(2):187-193.

19. Sambrook J, Russel DW: Molecular cloning: a laboratory manual. New York: Cold Spring Harbor Laboratory Press; 32001.

20. Birnboim HC, Doly J: A rapid alkaline extraction procedure for screening recombinant plasmid DNA. Nucleic Acids Res 1979, 7(6):1513-1523.

21. Zhou J, Bruns MA, Tiedje JM: DNA recovery from soils of diverse composition. Appl Environ Microbiol 1996, 62(2):316-322.

22. Xi F, Fu LY, Wang GZ, Zheng TL: A simple method for removing humic acids from marine sediment samples prior to DNA extraction. Chin High Technol Lett 2006, 16(5):539-544.

23. Roh C, Villatte F: Isolation of a low-temperature adapted lipolytic enzyme from uncultivated microorganism. J Appl Microbiol 2008, 105(1):116-123.

24. Altschul SF, Gish W, Miller W, Myers EW, Lipman DJ: Basic local alignment search tool. J Mol Biol 1990, 215(3):403-410.

25. Pearson WR: Rapid and sensitive sequence comparison with Fastp and Fasta. Method Enzymol 1990, 183:63-98.

26. Saitou N, Nei M: The Neighbor-Joining Method - a new method for reconstructing phylogenetic Trees. Mol Biol Evol 1987, 4(4):406-425.

27. Tamura K, Dudley J, Nei M, Kumar S: MEGA4: Molecular Evolutionary Genetics Analysis (MEGA) software version 4.0. Mol Biol Evol 2007, 24(8):1596-1599.

28. Thompson JD, Gibson TJ, Plewniak F, Jeanmougin F, Higgins DG: The CLUSTAL_X windows interface: flexible strategies for multiple sequence alignment aided by quality analysis tools. Nucleic Acids Res 1997, 25(24):4876-4882.

29. Hardeman F, Sjoling S: Metagenomic approach for the isolation of a novel low-temperature-active lipase from uncultured bacteria of marine sediment. FEMS Microbiol Ecol 2007, 59(2):524-534.

30. FJiang YQW H, Liu CG: Comparison and improvement of three determination methods for lipase activity. Chem Eng 2007, 24(8):72-75.

31. Pignede G, Wang HJ, Fudalej F, Gaillardin C, Seman M, Nicaud JM: Characterization of an extracellular lipase encoded by LIP2 in Yarrowia lipolytica. J Bacteriol 2000, 182(10):2802-2810.

32. Jaeger KE, Dijkstra BW, Reetz MT: Bacterial biocatalysts: molecular biology, three-dimensional structures, and biotechnological applications of lipases. Annu Rev Microbiol 1999, 53:315-351.

33. Panteghini $M$, Bonora $R$, Pagani F: Measurement of pancreatic lipase activity in serum by a kinetic colorimetric assay using a new chromogenic substrate. Ann Clin Biochem 2001, 38:365-370.

34. Zandonella G, Haalck L, Spener F, Faber K, Paltauf F, Hermetter A: Enantiomeric perylene-glycerolipids as fluorogenic substrates for a dual wavelength assay of lipase activity and stereoselectivity. Chirality 1996, 8(7):481-489.

35. Kim YJ, Choi GS, Kim SB, Yoon GS, Kim YS, Ryu YW: Screening and characterization of a novel esterase from a metagenomic library. Protein Expres Purif 2006, 45(2):315-323.

36. Ollis DL, Cheah E, Cygler M, Dijkstra B, Frolow F, Franken SM, Harel M, Remington SJ, Silman I, Schrag J, et al: The alpha/beta-hydrolase fold. Protein Eng 1992, 5(3):197-211.

37. Laurell H, Contreras JA, Castan I, Langin D, Holm C: Analysis of the psychrotolerant property of hormone-sensitive lipase through sitedirected mutagenesis. Protein Eng 2000, 13(10):711-717.

38. Verger R: 'Interfacial activation' of lipases: Facts and artifacts. Trends Biotechnol 1997, 15(1):32-38.

39. Jaeger KE, Eggert T: Lipases for biotechnology. Curr Opin Biotechnol 2002, 13(4):390-397.

40. Nawani N, Dosanjh NS, Kaur J: A novel thermostable lipase from a thermophilic Bacillus sp.: Characterization and esterification studies. Biotechnol Lett 1998, 20(10):997-1000.

41. De Simone G, Menchise V, Manco G, Mandrich L, Sorrentino N, Lang D, Rossi M, Pedone C: The crystal structure of a hyper-thermophilic carboxylesterase from the archaeon Archaeoglobus fulgidus. I Mol Biol 2001, 314(3):507-518.

42. De Simone G, Galdiero S, Manco G, Lang D, Rossi M, Pedone C: A snapshot of a transition state analogue of a novel thermophilic esterase belonging to the subfamily of mammalian hormone-sensitive lipase. $J$ Mol Biol 2000, 303(5):761-771.

doi:10.1186/1475-2859-9-83

Cite this article as: JunGang et al:: Cloning and biochemical

characterization of a novel lipolytic gene from activated sludge metagenome, and its gene product. Microbial Cell Factories 2010 9:83.

\section{Submit your next manuscript to BioMed Central and take full advantage of:}

- Convenient online submission

- Thorough peer review

- No space constraints or color figure charges

- Immediate publication on acceptance

- Inclusion in PubMed, CAS, Scopus and Google Scholar

- Research which is freely available for redistribution 